\title{
Student Peer-Reviewed Paper Competition
}

Students can win an award of $\$ 1350$ by contributing peer-reviewed articles to Cartographic Perspectives $(C P)$. Any peer-reviewed manuscript accepted for publication whose first author is a student, is automatically entered into the Student PeerReviewed Paper Competition, which is judged annually by the Editor and Editorial Board of $C P$.

\section{PAST WINNERS}

2016 Carolyn S. Fish An Analysis of Interactive Solar Energy Web Maps for Urban Energy Sustainability

2015 Joel Radunzel Using the Right Tool: David Woodward's Suggested Framerwork and the Study of Military Cartography

2014 Maxim Rylov Pairwise Line Labeling of Geographic Boundaries: An Efficient and Practical Algorithm

2013 Nick Perdue The Vertical Space Problem: Rethinking Population Visualizations in Contemporary Cities

2012 Bin Mo Mapping Potential Metro Rail Ridership in Los Angeles County

\section{OFFICIAL RULES}

1. Any manuscript accepted for publication without additional peer-review and having a student as a first author can be eligible for the competition. Specific requirements and stipulations include:

a. The first author must have been a student during the time that the research was conducted.

b. Manuscripts must be submitted by active students or graduates within a year of graduation.

c. The entire cash prize is awarded to the first author. Any distribution of this prize among other authors (whether students or others) is left to the discretion of the first author.

2. Upon acceptance of a manuscript, the student/ graduate will be asked to have his/her academic advisor submit a short note stating that this work was in fact completed during the time the student was in an academic program. A record of a student's graduation date may also be required for graduates submitting student research within one year of graduation.

3. Student papers will be judged annually, and include all papers published in the issues of Cartographic Perspectives for that calendar year.

4. Papers will be judged by a committee composed of members of the Editorial Board of CP. Each committee member will use the same rubric to evaluate all student papers. The rubric follows on the next page.

5. The editor will tally results of all rubrics. The paper with the highest overall score will be named winner of the competition at the next NACIS Annual Meeting. In the event of a tie, the editor will determine the winner. 


\section{EVALUATION RUBRIC}

\begin{tabular}{|c|c|c|c|c|c|c|}
\hline & $\begin{array}{l}\text { Fails to meet } \\
\text { expectations }\end{array}$ & $\begin{array}{c}\text { Meets } \\
\text { expectations }\end{array}$ & $\begin{array}{l}\text { Exceeds } \\
\text { expectations }\end{array}$ & $\begin{array}{l}\text { Greatly } \\
\text { Exceeds } \\
\text { expectations }\end{array}$ & Comments & Score \\
\hline $\begin{array}{l}\text { The abstract is a clear and } \\
\text { concise description of the }\end{array}$ & $\square$ & $\square$ & $\square$ & $\square$ & & \\
\hline paper. & 0 & 3 & 6 & 10 & & \\
\hline $\begin{array}{l}\text { The author introduces the } \\
\text { research problem succinctly }\end{array}$ & $\square$ & $\square$ & $\square$ & $\square$ & & \\
\hline $\begin{array}{l}\text { and clearly and explains the } \\
\text { purpose of the article. }\end{array}$ & 0 & 3 & 6 & 10 & & \\
\hline $\begin{array}{l}\text { The author addresses how } \\
\text { the present research fits into } \\
\text { previous research in the }\end{array}$ & $\square$ & $\square$ & $\square$ & $\square$ & & \\
\hline $\begin{array}{l}\text { appropriate cartographic } \\
\text { discipline. }\end{array}$ & 0 & 3 & 6 & 10 & & \\
\hline $\begin{array}{l}\text { The methodology/analysis } \\
\text { is technically/scientifically }\end{array}$ & $\square$ & $\square$ & $\square$ & $\square$ & & \\
\hline sound and well documented. & 0 & 3 & 6 & 10 & & \\
\hline $\begin{array}{l}\text { The results are valid or } \\
\text { the design innovation is } \\
\text { shown to be useful/effective }\end{array}$ & $\square$ & $\square$ & $\square$ & $\square$ & & \\
\hline $\begin{array}{l}\text { AND the results or design } \\
\text { innovation are presented/ } \\
\text { illustrated clearly. }\end{array}$ & 0 & 3 & 6 & 10 & & \\
\hline $\begin{array}{l}\text { The discussion addresses } \\
\text { the way in which the } \\
\text { research aligns with existing }\end{array}$ & $\square$ & $\square$ & $\square$ & $\square$ & & \\
\hline $\begin{array}{l}\text { knowledge or design } \\
\text { practice and its implications } \\
\text { for future work. }\end{array}$ & 0 & 3 & 6 & 10 & & \\
\hline $\begin{array}{l}\text { The conclusions state the } \\
\text { most important findings of }\end{array}$ & $\square$ & $\square$ & $\square$ & $\square$ & & \\
\hline the research. & 0 & 3 & 6 & 10 & & \\
\hline Novelty and significance/ & $\square$ & $\square$ & $\square$ & $\square$ & & \\
\hline potential impact on the field. & 0 & 3 & 6 & 10 & & \\
\hline $\begin{array}{l}\text { Maps and illustrations } \\
\text { are well designed and }\end{array}$ & $\square$ & $\square$ & $\square$ & $\square$ & & \\
\hline communicate effectively. & 0 & 3 & 6 & 10 & & \\
\hline $\begin{array}{l}\text { Writing is organized, } \\
\text { grammatically correct, clear }\end{array}$ & $\square$ & $\square$ & $\square$ & $\square$ & & \\
\hline and concise. & 0 & 3 & 6 & 10 & & \\
\hline
\end{tabular}

